\title{
Proteomics and Lipidomics Investigations to Decipher the Behavior of Willaertia magna C2c Maky According to Different Culture Modes
}

\author{
Issam Hasni 1,2,3, Nicholas Armstrong 1,3 , Philippe Decloquement 1,3 , Said Azza 1,3, \\ Anthony Fontanini ${ }^{3}$, Olivier Abbe ${ }^{2}$, Amina Cherif Louazani 1,3 ${ }^{\mathbb{D}}$, Sandrine Demanèche ${ }^{2}$, \\ Eric Chabrière ${ }^{1,3}$, Philippe Colson 1,3 (D) and Bernard La Scola $1,3, *$ (D) \\ 1 Aix-Marseille Université UM63, Faculté des Sciences Médicales et Paramédicales secteur Timone, \\ Institut de Recherche Pour le Développement IRD 198, Assistance Publique-Hôpitaux de \\ Marseille (AP-HM), 13385 Marseille, France; issemhasni@gmail.com (I.H.); \\ nicholas.armstrong@univ-amu.fr (N.A.); Philippe.DECLOQUEMENT@univ-amu.fr (P.D.); \\ said.azza@univ-amu.fr (S.A.); cheriflamina@gmail.com (A.C.L.); eric.chabriere@univ-amu.fr (E.C.); \\ philippe.colson@univ-amu.fr (P.C.) \\ 2 R\&D Department, Amoéba, 69680 Chassieu, France; o.abbe@amoeba-nature.com (O.A.); \\ s.demaneche@amoeba-nature.com (S.D.) \\ 3 Institut Hospitalo-Universitaire (IHU), Microbes, Evolution, Phylogeny and \\ Infection (MEФI)—Méditerranée Infection, 13005 Marseille, France; fontanini.anthony@gmail.com \\ * Correspondence: bernard.la-scola@univ-amu.fr; Tel.: +33-491324375; Fax: +33-491387772
}

Received: 10 September 2020; Accepted: 14 November 2020; Published: 16 November 2020

\begin{abstract}
Willaertia magna C2c Maky is a free-living amoeba that has demonstrated its ability to inhibit the intracellular multiplication of some Legionella pneumophila strains, which are pathogenic bacteria inhabiting the aquatic environment. The Amoeba, an industry involved in the treatment of microbiological risk in the water and plant protection sectors, has developed a natural biocide based on the property of W. magna to manage the proliferation of the pathogen in cooling towers. In axenic liquid medium, amoebas are usually cultivated in adhesion on culture flask. However, we implemented a liquid culture in suspension using bioreactors in order to produce large quantities of W. magna. In order to investigate the culture condition effects on W. magna, we conducted a study based on microscopic, proteomics and lipidomics analyzes. According to the culture condition, amoeba exhibited two different phenotypes. The differential proteomics study showed that amoebas seemed to promote the lipid metabolism pathway in suspension culture, whereas we observed an upregulation of the carbohydrate pathway in adherent culture. Furthermore, we observed an over-regulation of proteins related to the cytoskeleton for W. magna cells grown in adhesion. Regarding the lipid analysis, suspension and adhesion cell growth showed comparable lipid class compositions. However, the differential lipid analysis revealed differences that confirmed cell phenotype differences observed by microscopy and predicted by proteomics. Overall, this study provides us with a better insight into the biology and molecular processes of W. magna in different culture lifestyles.
\end{abstract}

Keywords: Willaertia magna C2c Maky; amoebas; culture; proteomics; lipidomics; metabolism

\section{Introduction}

Willaertia magna is a free-living amoeba (FLA) belonging to the class Heterolobosea and family Vahlkampfiidae [1,2]. This FLA is found in natural and artificial environments, such as humid soil, bovine feces, composts, thermal waters, and fresh water sediments [3-5]. W. magna life cycle is composed of three stages switching between trophozoite form, flagellate form and cyst form [1]. 
The trophozoites stage is characterized by a large form containing one or several nuclei, food and contractile vacuoles, and mitochondria. The phagotrophic trophozoites feed on bacteria and can grow within a range of $22^{\circ} \mathrm{C}$ to $44^{\circ} \mathrm{C}$ [4]. The amoeboid form can temporary transform into ameboflagellate under certain conditions [6]. To resist unfavorable conditions, the trophozoite has the capacity to transform into large cysts containing pores in the cell wall [4]. Although W. magna is phylogenetically close to Naegleria fowleri, a virulent amoeba causing primary amoebic meningoencephalitis (PAM) in humans, in vivo and in silico experiments have demonstrated the non-pathogenicity of W. magna [4,7,8]. The analysis of the W. magna draft genome revealed a DNA length of 36.5 megabases and less than 19,000 genes [8].

Legionella pneumophila is a Gram-negative bacterium causing legionellosis, a severe and potentially fatal pneumonia in humans [9]. Although L. pneumophila is ubiquitous in natural water environment [10], the numerous cases of legionellosis are mainly due to the inhalation or respiration of pathogenic bacteria present in engineering water systems, such as cooling towers where legionella finds suitable growing condition [11-13]. Furthermore, the co-existence of FLAs and L. pneumophila complicates the monitoring of the latter in cooling tower waters [14,15]. L. pneumophila strains have the capacity to infect and invade a wide range of amoebas, including Vermamoeba, Acanthamoeba, and Naegleria species [12,16-18]. Furthermore, amoeba cysts provide to L. pneumophila a protection against harsh conditions and chemical treatments [15]. Regarding W. magna strain C2c Maky, it has been shown to be capable of phagocyting and inhibiting the intracellular growth of certain human pathogenic strains of L. pneumophila $[19,20]$.

This finding led the Amoeba company, an industry involved in the sanitation of water in cooling towers and in the treatment of plant protection, to develop a natural biocide to monitor and prevent L. pneumophila proliferation water in cooling towers as an alternative to chemical biocides that are not completely efficient [21]. However, the treatment of water in cooling towers by this mean requires large quantities of W. magna. The traditional culture of amoebas is performed on agar plate or liquid support in xenic or axenic medium. Nevertheless, these culture methods do not allow to obtain large amounts of amoebas in a short time [22]. Axenic mass culture of Acanthamoeba castellanii in bioreactors has already been shown to improve the production of this amoeba [23]. In a previous study, Weekers et al. have carried out the axenic culture of $A$. castellanii in a fermenter and analyzed the behavior of this amoeba by investigating different parameters of the growth process, such as glucose consumption, amoeba concentration or respiration [24]. In another study, the behavior of Dictyostelium discoideum during a culture in suspension was investigated [22].

According to the culture conditions, the organisms need to regulate their metabolism and to mediate molecular responses in order to adapt to various environments [25]. Indeed, variations in gene expression and protein synthesis lead to different phenotypes and allow adaptation to distinct environments. Furthermore, it is known that the culture condition has an effect on the morphology, proteome and lipid composition of cellular organisms [25-27]. So far, the behavior of amoebas grown under different growing conditions remains unclear, especially for suspension and adhesion cell growth [28,29]. Over the past few decades, multi-omics approaches, including genomics, transcriptomics, proteomics, or lipidomics analyses have become essential tools for exploring the biology, behavior, molecular mechanisms, or metabolism of organisms [30-32]. However, these methods have not yet been widely applied to study FLAs. Indeed, only a few studies based on genomics, transcriptomics and proteomics are described in the literature [8,33-42].

In a previous study, we explored the behavior of W. magna C2c Maky in suspension culture by transcriptomics and proteomics analyzes [33]. To decipher the effect of culture conditions on W. magna C2c Maky, we explored the morphologic differences of W. magna growing in two culture modes by microscopic analysis. Then, we investigated the differential regulation of proteins for W. magna cultivated according to two different culture methods. Finally, an analysis of lipid classes was performed to further decipher the W. magna phenotype associated with the culture methods. 


\section{Materials and Methods}

\subsection{Culture of Willaertia magna C2c Maky in Adhesion}

Culture of Willaertia magna C2c Maky (ATCC PTA-7824) was performed at $30^{\circ} \mathrm{C}$ (Thermo Fisher Scientific, Illkirch, France) using $175 \mathrm{~cm}^{2}$ culture flasks in SCGYEM medium [43]. When the trophozoite formed a monolayer, the amoebas were detached by tapping the culture flasks and harvested by centrifugation at $2000 \times \mathrm{g}$ during $10 \mathrm{~min}$, followed by three steps of washing using page's amoeba saline (PAS) medium ( $2 \mathrm{mM} \mathrm{NaCl}, 16 \mu \mathrm{M} \mathrm{MgSO}_{4}, 27.2 \mu \mathrm{M} \mathrm{CaCl}_{2}, 1 \mathrm{mM} \mathrm{Na} \mathrm{HPO}_{4}, 1 \mathrm{mM} \mathrm{KH}_{2} \mathrm{PO}_{4}$ ). Amoeba quantification was performed using a KOVA ${ }^{\circledR}$ slide cell counting chamber.

\subsection{Culture of Willaertia magna C2c Maky in Suspension}

W. magna C2c Maky was cultivated in a 10-L bioreactor (GPC, La Rochelle, France; [44]) in modified SCGYEM medium without fetal calf serum $(\mathrm{pH}=7)$, as previously described [37]. To perform morphologic, proteomics, and lipidomics analyses, the amoeba cells were harvested from bioreactor in a volume of $50 \mathrm{~mL}$, and centrifugated at $2000 \times \mathrm{g}$ for $10 \mathrm{~min}$ and washed in three steps using PAS medium. Amoeba quantification was performed using a KOVA ${ }^{\circledR}$ slide cell counting chamber.

\subsection{Protein Extraction}

Amoebas were harvested from three different bioreactors or three different flasks in order to perform a proteomics study on three biological replicates. For each condition, we put $40 \mathrm{~mL}$ of amoebas at $10^{6}$ amoebas/mL in $50 \mathrm{~mL}$ falcon tubes (Dutscher SAS, Brumath, France) in medium culture. The amoebas were rinsed with PAS and centrifugated at $2000 \times g$ for $10 \mathrm{~min}$. Four sets of samples from each W. magna of different condition culture were prepared for label-free Nano-LC-MS/MS analysis. Each sample was solubilized as previously described [45]. Briefly, samples were suspended in $200 \mu \mathrm{L}$ of lysis buffer (100 mM Tris- $\mathrm{HCl}, \mathrm{pH} 8.0$, supplemented with $2 \%$ (wt/vol) sodium dodecyl sulfate and $100 \mathrm{mM}$ dithiothreitol) followed by $5 \mathrm{~min}$ of heating at $95^{\circ} \mathrm{C}$. After a 3-min sonication at $20 \mathrm{~W}$, the insoluble fraction was removed by centrifugation $(12,000 \times g, 20 \mathrm{~min})$ and soluble proteins were precipitated using a PlusOne 2-D cleanup kit (GE Healthcare) to remove SDS. The final pellet was resuspended in $200 \mu \mathrm{L}$ of solubilization buffer (Urea 8M, Thiourea 2M, $100 \mathrm{mM} \mathrm{NaCl}, 25 \mathrm{mM}$ Tris, $\mathrm{pH}$ 8.2) and dialyzed twice against $1 \mathrm{~L}$ of $50 \mathrm{mM}$ ammonium bicarbonate $\mathrm{pH} 7.4$, Urea $1 \mathrm{M}$ ( $4 \mathrm{~h}$ and overnight) using Slide-ALyzer Dialysis Cassettes 2K MWCO (Pierce Biotechnology, 122 Rockford, IL, USA). Dialyzed fractions were collected, and proteins were quantified by Bradford assay using Coomassie (Biorad). The dialyzed fraction was used as template for global proteomic analysis. Briefly, $50 \mu \mathrm{g}$ of total soluble proteins were reduced with $10 \mathrm{mM}$ dithiothreitol (Euromedex, Souffelweyersheim, France) for one hour at $30{ }^{\circ} \mathrm{C}$, and then alkylated with $20 \mathrm{mM}$ iodoacetamide (Sigma, Saint-Quentin Fallavier, France) for one hour in the dark. Protein digestion was performed by adding $2 \mu \mathrm{g}$ of sequencing-grade trypsin solution (Promega, Charbonnières, France) to alkylated proteins and incubated overnight at $37^{\circ} \mathrm{C}$. The digested sample was then desalted using Pierce Detergent Removal Spin Columns (Thermo Fisher Scientific, Illkirch, France) and analyzed by mass spectrometry, as described below. For the three biological replicates of amoebas cultivated in adhesion, we obtained protein concentrations of 1.9, 2.5, and $1.1(\mu \mathrm{g} / \mu \mathrm{L})$ respectively. For amoebas cultivated in suspension, we obtained protein concentrations of $4.4,4.7$, and $4.7(\mu \mathrm{g} / \mu \mathrm{L})$. Table S1 presents the complete results obtained from protein extraction.

\subsection{Label-Free Quantitative Nano-LC-MS/MS Proteomic Analysis}

Protein digests were first separated by Ultra Performance Liquid Chromatography (UPLC) using the NanoAcquity UPLC System (Waters, Milford, CT, USA) connected to a Synapt G2Si Q-TOF ion mobility hybrid mass spectrometer (Waters). The chromatographic system was used in 1D configuration with an analytical column (ACQUITY UPLC M-Class peptide CSH C18 Column, $130 \AA 1.7 \mu \mathrm{m}, 75 \mu \mathrm{m} \times 100 \mathrm{~mm}$, Waters) after a trapping column (ACQUITY UPLC M-Class Symmetry C18 Trap Column, 100Å $5 \mu \mathrm{m}$ 2G V/M, $180 \mu \mathrm{m} \times 20 \mathrm{~mm}$, Waters). Eluted peptides were then separated 
using a $100 \mathrm{~min}$ gradient ( $300 \mathrm{~nL} \cdot \mathrm{min}^{-1} ; 0.5$ to $40 \%$ acetonitrile- $0.1 \%$ formic acid). Data-independent MS/MS analysis was performed with the ion mobility feature (HDMSe method). The parameters of ion source were as follows: Capillary voltage at $3 \mathrm{kV}$, sampling cone voltage at $40 \mathrm{~V}$, ion source temperature at $90{ }^{\circ} \mathrm{C}$, cone gas flow at $50 \mathrm{~L} \cdot \mathrm{h}^{-1}$. Transfer collision low energy was set to $5 \mathrm{~V}$ and trap collision low energy was set to $4 \mathrm{~V}$. The high energy ramp was applied from $4 \mathrm{~V}$ to $5 \mathrm{~V}$ for the trap collision and from $19 \mathrm{~V}$ to $45 \mathrm{~V}$ for the transfer collision enabling fragmentation of the ions after the ion mobility cell and before the time-of-flight (TOF) MS. Each sample was injected in triplicate.

The acquired files were imported into Progenesis QI software Version 2.0 (Nonlinear Dynamics, Newcastle, UK) for label-free quantification analysis. The data were automatically aligned against W. magna proteins (https://www.mediterranee-infection.com/acces-ressources/donnees-pour-articles/ willaertia-magna-c2c-maky/) and normalized. Processing parameters were 150 counts for the low energy threshold and 30 counts for the elevated energy threshold. The database used was the same as the one described above. Search tolerance parameters were peptide and fragment tolerance, $15 \mathrm{ppm}$, FDR $<1 \%$; Minimum Ion matching requirements were three fragments per peptide, seven fragments per protein and two peptides per protein. The enzyme specificity was trypsin allowing 1 missed cleavage. The accepted modifications were carbamidomethyl of cysteine (fixed), oxidation of methionine (variable), carbamylation of lysine and N-terminal (variable), and deamidation (variable) of asparagine and glutamine. Protein normalization was performed according to the relative quantitation using non-conflicting peptides. To determine the significance of changes between samples, a significant ANOVA ( $p$-value $<0.001$ ) and a fold change greater than 2 were used as thresholds to define differently regulated proteins (DRPs). The results obtained from proteomics analysis are detailed in Table S2.

\subsection{Analysis on Biological Function of Differentially Regulated Proteins}

To assign the biological functions of DRPs, we proceeded to homology searches for the proteins in public protein databases. First, the protein sequences were searched by BLASTp against the NCBI non redundant protein sequence database with an E-value cut-off of $1 \times 10^{4}$ [46]. We mapped the protein sequences against the Cluster of Orthologous Group of proteins (COG) and Gene Ontology (GO) databases using EggNOG $[47,48]$ with diamond as mapping mode. The visualization of GO annotation was performed using WEGO online software [49]. In a second time, we compared the protein sequences against the Kyoto Encyclopedia of Genes and Genomes Pathway (KEGG; http://www.genome.jp/kegg) using BLASTKoala online [50]. Conserved domain database (CDD) and InterPro were used for the identification of conserved domains in the sequence of DRPs [51-53].

\subsection{Quantitative Real-Time Reverse-Transcription-Polymerase Chain Reaction (qRT-PCR)}

In order to validate the DRP results, 10 genes encoding DRPs were selected to quantify their expression by real-time quantitative reverse transcription PCR (qRT-PCR) using SYBR Green (Roche, Meylan, France) and 1 gene encoding a histone protein was used as internal control. To choose the internal control, we identified the set of proteins whose regulation was not affected by culture conditions. Among these proteins, we selected a panel of candidate genes. We quantified expression level of these candidate genes under two different culture conditions (suspension and adhesion). We selected the most stable gene among the set of reference candidate genes tested. RNAs from W. magna in each culture condition were extracted using the RNeasy Mini Kit (Qiagen Corp., Hilden, Germany) following the manufacturer's protocol. Total RNA was eluted in a $50 \mu \mathrm{L}$ volume of RNase-free water. RNaseOUT (Thermo Fisher Scientific, Illkirch, France) was added to the eluate to prevent RNA degradation. DNA digestion was performed using Turbo DNase (Life Technologies, Carlsbad, USA) at $37^{\circ} \mathrm{C}$ for $4 \mathrm{~h}$. The design of primer for each gene was performed using the Primer3 website (http://frodo.wi.mit.edu/primer3/). Primers are listed in Table S3. Extracted RNAs were reverse transcribed into cDNA using random primers with the SuperScript VILO Synthesis Kit (Invitrogen, Cergy-Pontoise, France). The synthesized cDNAs were purified with the Agencourt AMPure XP system (Beckman Coulter Inc., Brea, CA, USA). Quantitative PCR was carried out in a CFX96 real time system 
(Biorad) using the following cycling conditions: $95^{\circ} \mathrm{C}$ for $5 \mathrm{~min}$, followed by 45 cycles of $95^{\circ} \mathrm{C}$ for $10 \mathrm{~s}$, annealing at $60^{\circ} \mathrm{C}$ for $30 \mathrm{~s}$ and elongation at $72{ }^{\circ} \mathrm{C}$ for $30 \mathrm{~s}$. As in Li et al.'s study, the relative expression (fold change) of each gene was calculated with the $2-\Delta \Delta \mathrm{Ct}$ method and statistics were generated using Student's $t$-test $[54,55]$. All experiments were performed with three biological replicates.

\subsection{Analysis of Lipid Classes by Hydrophilic Interaction Liquid Chromatography-Mass Spectrometry (HILIC-MS)}

For each condition, triplicate amoeba cultures were centrifuged at $6000 \times g$ during $10 \mathrm{~min}$ in order to collect humid cell pellets. Total lipids were extracted according to the Bligh and Dyer protocol [56]. Chloroform extracts were then dried under a stream of nitrogen and reconstituted in chloroform/methanol 50\% $(v: v)$ at a final concentration of $6 \mathrm{mg}$ of lipid content per $100 \mu \mathrm{L}$. Lipid samples were diluted 100 times into methanol before injection $(5 \mu \mathrm{L})$ onto a HILIC column (BEH HILIC, $2.1 \times 100 \mathrm{~mm}, 1.7 \mu \mathrm{m}$, Waters, Guyancourt, France). Lipids were eluted from the column using a composition gradient of the following solvents: $\mathrm{A}=5 \%$ water $/ 95 \%$ acetonitrile, $\mathrm{B}=50 \%$ water $/ 50 \%$ acetonitrile, both at $10 \mathrm{mM}$ ammonium acetate $\mathrm{pH} 8$ as previously described [57]. Lipids were ionized in the positive and negative ionization modes using a Z-spray source $(2.8 \mathrm{kV}, 35 \mathrm{~V}$ for ESI+ and $1.9 \mathrm{kV} 40 \mathrm{~V}$ for ESI-). Ions were then monitored using an HD-MS method including ion mobility and single stage MS scans (ranged from 50 to $2000 \mathrm{~m} / \mathrm{z}$, $0.1 \mathrm{~s}$ per scan, lockmass calibration using Leucine Enkephaline). Multivariate statistics were performed for each ionization mode on all detected ion components using the UNIFI and EZ info software (with normalization of data) [58]. A PLS-DA model was calculated from the principal component analysis (PCA) in order to select form S-Plot (>97\%) and VIP (>1) plots, the most discriminating markers for both culture conditions. Lipid classes were attributed according to the retention times of an injected standard (Splash Lipidomix, Avanti Polar Lipids, Alabaster, AL, USA). Markers masses were then searched with the COMP DB LipidMAPS database with a delta window of $0.005 \mathrm{~m} / \mathrm{z}$ and all enabled chains. The database lipid charge was checked versus the ion component extracted from the MS raw data.

\subsection{Fatty Acid Methyl Ester (FAME) Analysis by Gas Chromatography/Mass Spectrometry}

Cellular fatty acid methyl ester (FAME) analysis was performed by GC/MS, as previously described [59,60]. Fatty acid methyl esters were prepared as described by M. Sasser [61]. Briefly, fatty acid methyl esters were analyzed by gas chromatography/mass spectrometry (GC/MS). Compounds were separated using an Elite 5-MS column and monitored by mass spectrometry (Clarus 500-SQ 8 S, Perkin Elmer, Courtaboeuf, France). Spectral database search was performed using MS Search 2.0 operated with the Standard Reference Database 1A (NIST, Gaithersburg, MD, USA) and the FAMEs mass spectral database (Wiley, Chichester, UK).

\subsection{Electron Microscopy}

For scanning electronic microscopy, a suspension of W. magna in trophozoite forms (for the amoebas cultivated in suspension and in adhesion) form was immersed into a $2.5 \%$ glutaraldehyde fixative solution. A drop of the suspension was deposited on a slide, then gently washed with water, air-dried and examined under the Emission Scanning Electron Microscope SU5000 (approximately $33 \mathrm{~cm}$ wide by $60 \mathrm{~cm}$ tall, Hitachi, Japan).

\section{Results}

\subsection{Phenotype of Willaertia magna Cultivated under Two Different Conditions}

The adherent amoebas exhibited an irregular shape that constantly changed giving rise to the presence of several pseudopods (Figure 1A,B). The suspended amoebas exhibited a more regular shape with a more rounded morphology and exhibited much fewer pseudopods (Figure 1C,D). The length of the amoebas cultivated under two different conditions exhibited approximately similar 
size, with length of $21 \mu \mathrm{m}(+/-3.34)$ and $19.5 \mu \mathrm{m}(+/-4.50)$ for the amoeba grown in adhesion and suspension, respectively (Table $\mathrm{S} 4$ ).

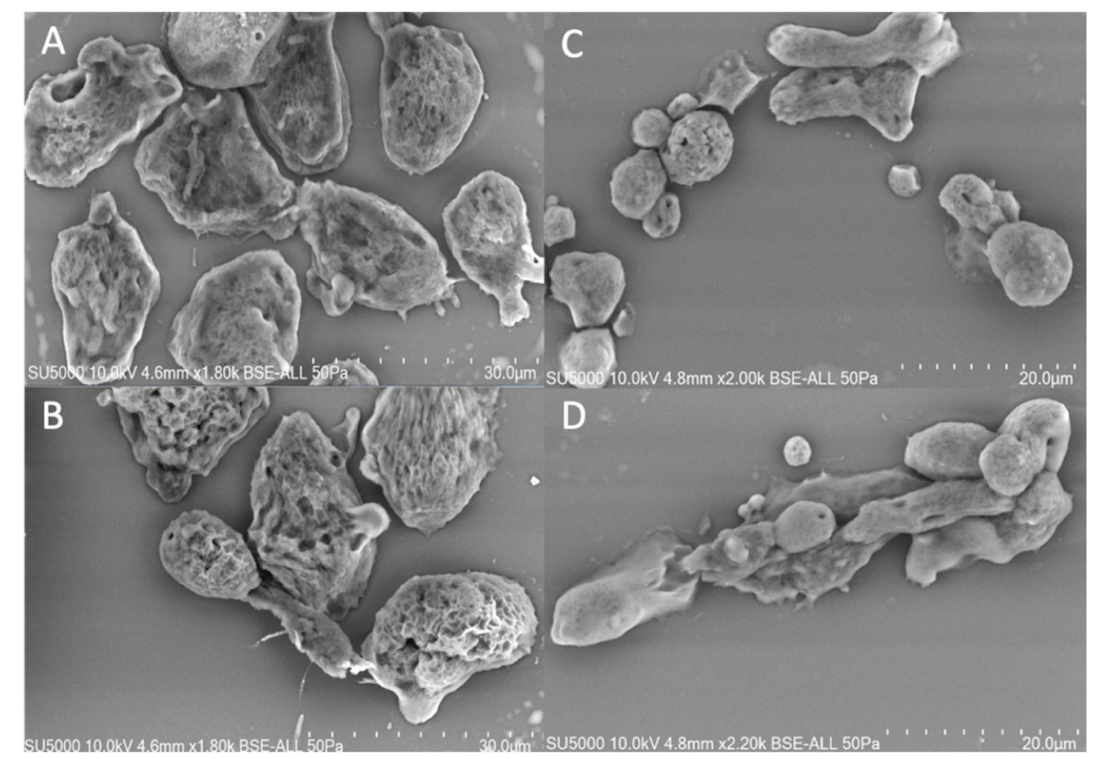

Figure 1. Morphology of Willaertia magna cultivated under two different culture conditions. In (A,B): W. magna is cultivated in adhesion on cell culture flask. In (C,D): W. magna is cultivated in suspension in bioreactor. Pictures were obtained with emission Scanning Electron Microscope SU5000 (Hitachi, Japan). Bar scales are represented on picture.

However, the amoeba in adhesion $(14.2 \mu \mathrm{m})$ is approximately 3 times width than the cultivated amoebas in bioreactor $(5.2 \mu \mathrm{m})$. We observed the presence of pseudopodia for amoebas in adhesion, which is characteristic of the active movement of the amoebas.

\subsection{Identification of Differentially Regulated Proteins}

A total of 804 non-redundant proteins were identified using UPLC. The significance of differences in protein abundance was established using $p \leq 0.001$ and $|\mathrm{FC}| \geq 2$ as thresholds (Table S5). Based on these criteria, 61 differentially regulated proteins (DRPs) were detected between W. magna cultivated in suspension and adhesion, of which $21(34.4 \%)$ were down-regulated and $40(65.6 \%)$ were up-regulated in adhesion compared with suspension cell growth (Table S5).

Among the 61 DRPs, 32 had a function assigned in the NCBI nr database, whilst 28 proteins had an uncharacterized function, including 5 hypothetical proteins, 21 predicted proteins and 2 ORFans. Most of the proteins $(n=52)$ had best hits with Naegleria gruberi, a free-living amoeba phylogenetically close to W. magna (Table S5). The proteins exhibiting the greatest differential abundance between the two conditions were proteins with unknown functions for amoebas in both suspension and adhesion culture (Table S5).

A total of 48 DRPs (78.7\%) identified by proteomics analysis, were classified into 14 COG categories, among which "post-translational modification, protein turnover, chaperones" represented the largest group (group O, 12 DRPs), followed by "energy production and conversion" (group C, 8 DRPs) and "translation, ribosomal structure and biogenesis" (group J, 5 DRPs) (Figure 2, Table S5). 
Post-translational modification, protein turnover, and chaperones

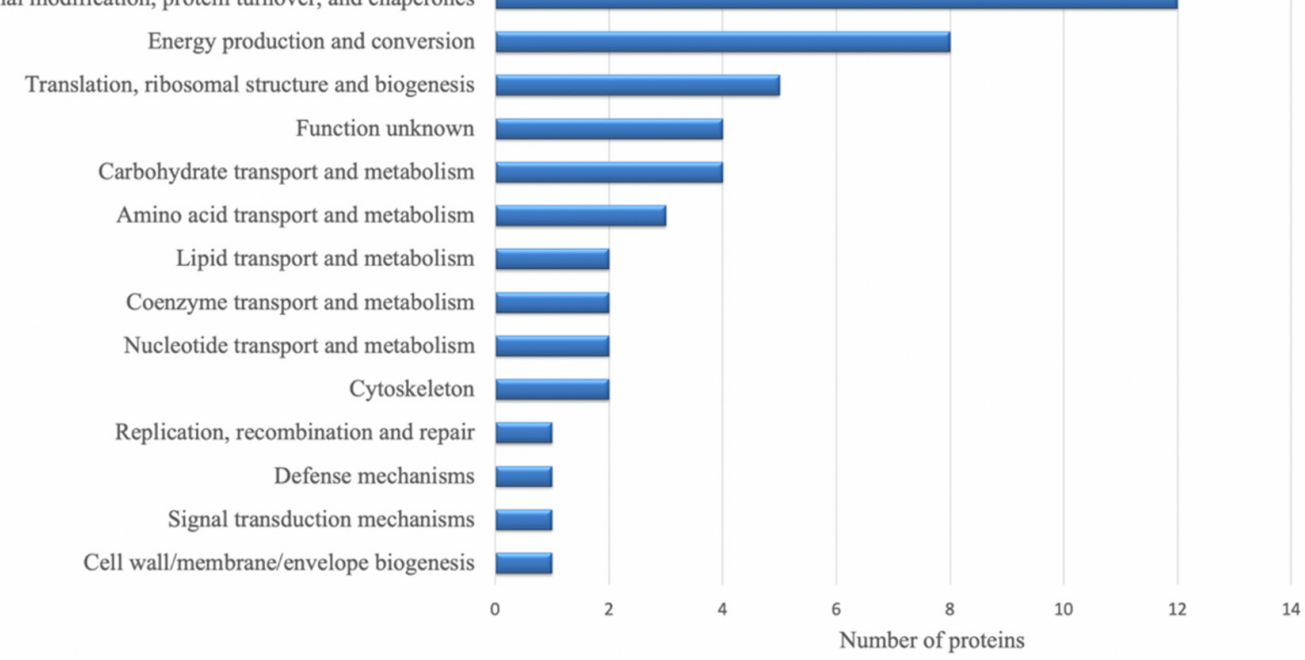

Figure 2. Representation of differently regulated proteins (DRPs) matching with a function in the Cluster of Orthologous Group of proteins (COG) database.

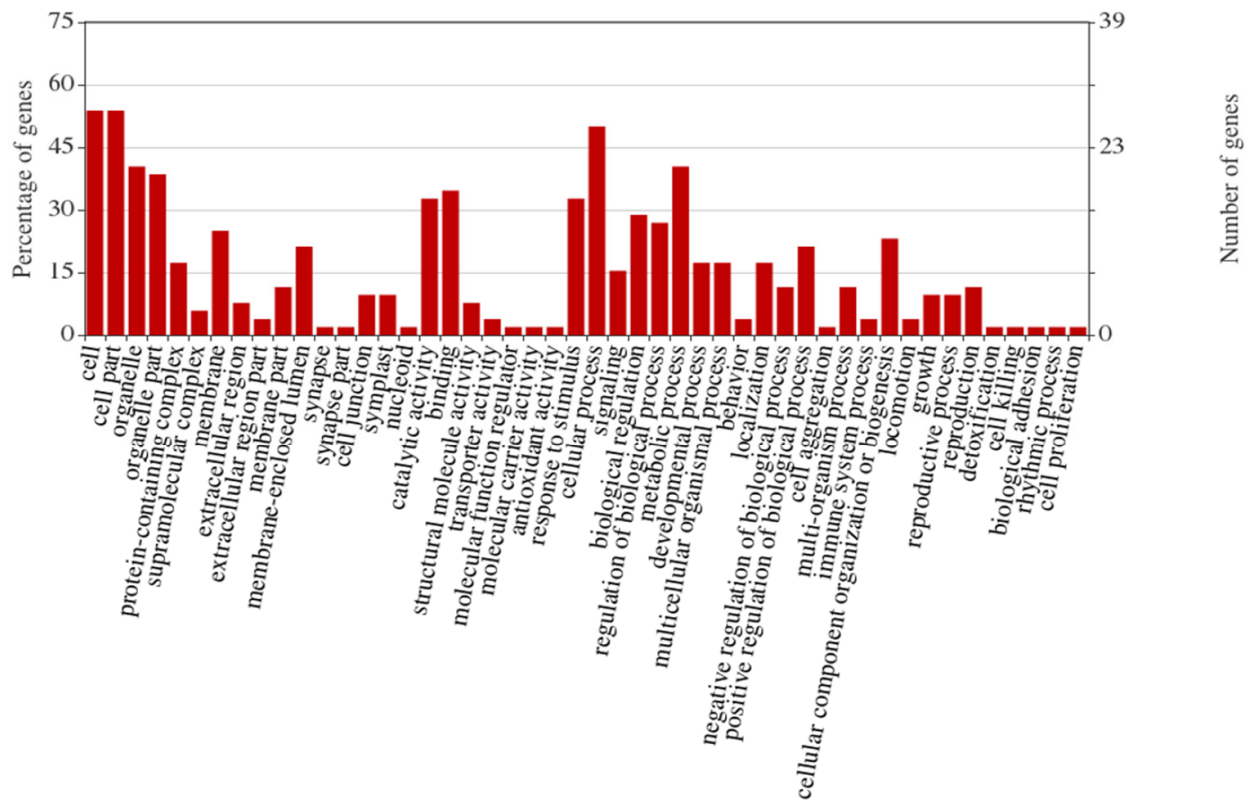

Cellular Component Molecular Function Biological Process

Figure 3. Gene Ontology (GO) distribution plotted by WEGO. The proteins were assigned to three main categories: biological process, molecular function and cellular component. The right-hand $\mathrm{y}$-axis indicates the number of annotated proteins. The left-hand $y$-axis indicates the percentage of annotated proteins.

GO analysis was carried out to obtain fundamental function of genes and information on molecular functions, cellular components and biological processes. After mapping the DRPs against the GO database, we observed that 28 genes (45\%) were assigned to GO terms. A same gene could be involved in different GO terms. Genes among the following classes: biological process (27), cellular process (26), metabolic process (21) and response to stimulus (17) were the most abundant. For molecular function (26), the dominant group was binding (18) followed by catalytic activity (17) and structure molecular 
activity (4). For the cellular components (28), the three most prevalent groups were cell (28), cell part (28) and organelle (21) (Figure 3).

To investigate the biological functions and metabolic pathways of protein sequences, we performed an enrichment analysis with the KEGG pathway database. Among the 61 DRPs, 45 (72.6\%) DRPs were mapped to 22 pathways in the KEGG database. The proteins involved in metabolic pathways were the most represented $(n=12 ; 27 \%)$, followed by those involved in cellular processes $(13 \%)$ and genetic information processing (13\%). KEGG enrichment indicated that most of these DRPs were involved in carbohydrate metabolism, such as citrate cycle and glycolysis/gluconeogenesis. We also identified some DRPs involved in "nucleotide metabolism" $(n=1 ; 2 \%)$ and "lipid metabolism" ( $n=1 ; 2 \%)$ (Figure 4).

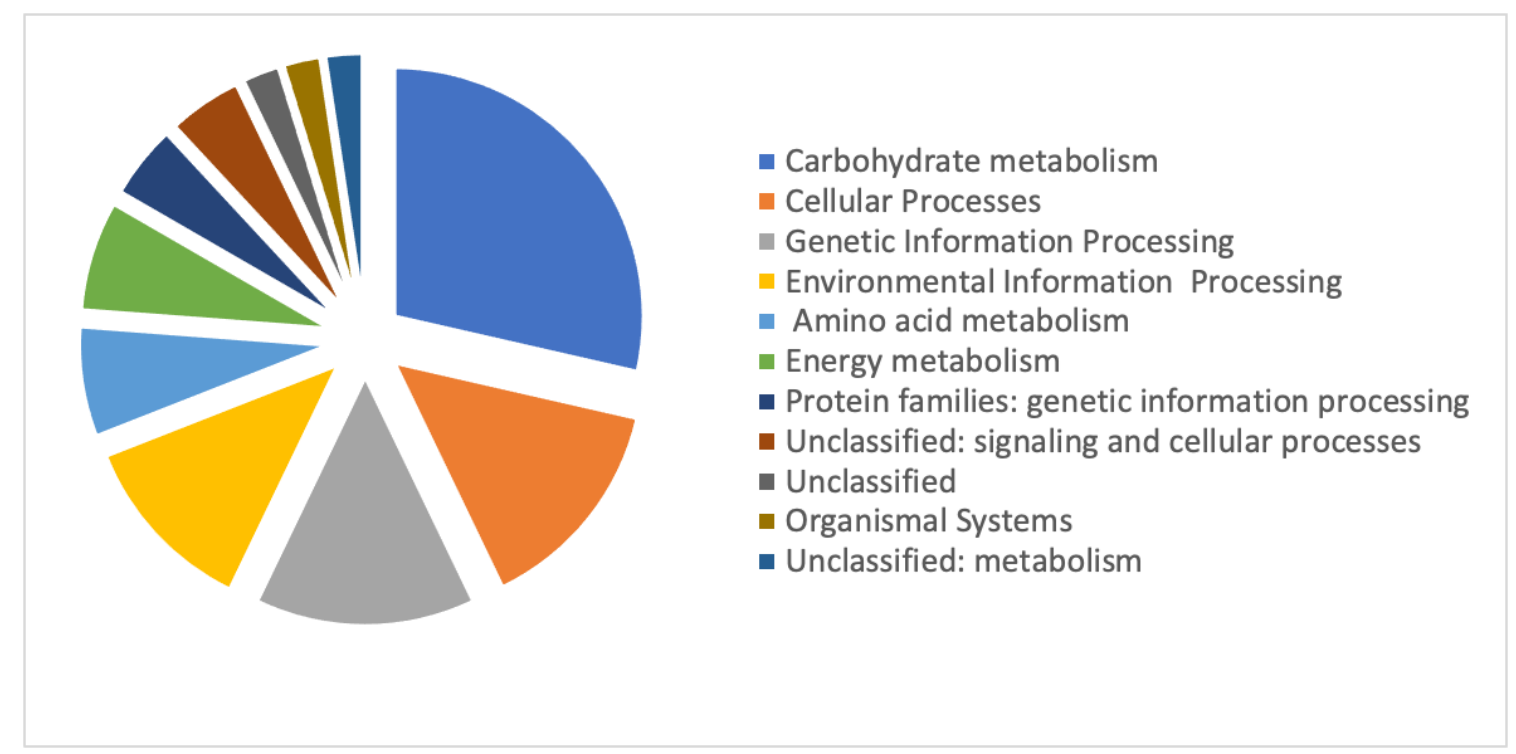

Figure 4. Representation of DRPs matching with a function in the Kyoto Encyclopedia of Genes and Genomes Pathway (KEGG) database. Each protein was classified in a KEGG category.

\subsection{Identities of Differentially Regulated Proteins}

Among the DRPs identified for the amoebas cultivated in adhesion, we found actin alpha, actin beta, tubulin, and profilin proteins (Table 1). These four proteins are related to the cytoskeleton organization. Of the 40 DRPs in adhesion cell growth, a high number $(n=13 ; 31 \%)$ were found related to metabolisms. Most of these proteins are involved in carbohydrate metabolism, including malate dehydrogenase, pyruvate dehydrogenase, glyceraldehyde 3-phosphate dehydrogenase, triose phosphate isomerase, or citrate synthase (Table 1). Furthermore, we observed an upregulation of 4 proteins involved in the nucleotide and amino acid pathway, such as glutamate dehydrogenase or cystathionine gamma-synthase (Table 1). In addition to the proteins related to metabolisms, the analysis revealed in adhesion cell growth a high abundance of proteins related to energy, signaling and redox regulation (thioredoxin) (Table 1). In a previous study, we reported the presence of proteins specifically related to defense mechanism in the proteome of W. magna cultivated in suspension [33]. In our differential proteomic analysis, we recovered some of these proteins related to the mechanism, including four cathepsin proteins involved in catabolism and lysosomal protease. These cathepsins were the only proteins related to the defense mechanisms that were differentially regulated according to the culture method (Table 1). For the cells cultivated in suspension, we reported an upregulation in suspension cell growth of proteins related to stressful conditions such as the heat shock condition $(n=4$, heat shock proteins) (Table 2). In addition, we observed the over-regulation of two proteins playing a role in the membrane structure and four proteins involved in metabolism pathways, including lipid (5 long-chain acyl-CoA synthetase and alcohol dehydrogenase) and amino acid metabolisms (maleylacetoacetate isomerase and 5-methyltetrahydropteroyltriglutamate-homocysteine methyltransferase) (Table 2). 
Finally, two proteins (large subunit ribosomal protein L7/L12 and Ran GTPase binding) related to genetic information were found to be over-regulated and three were down-regulated in suspension cell growth (large subunit ribosomal protein L24e, large subunit ribosomal protein L23e and RRM domain-containing protein) (Tables 1 and 2). To complete the differential proteomic analysis, we also investigated the expression levels by qRT-PCR of 10 selected genes encoding DRPs. The transcription levels of these 10 mRNAs were correlated with the results of differential proteomics analysis (Figure S1 and Table S3).

Table 1. Willaertia magna proteins up-regulated in adhesion and down-regulated in suspension culture.

\begin{tabular}{|c|c|c|c|}
\hline $\begin{array}{c}\text { Protein Sequence } \\
\text { Accession of } W . \text { magna }\end{array}$ & Anova (p) & Fold Change & Protein Function \\
\hline protein 17463 & $1.45 \times 10^{-14}$ & 410.39 & predicted protein \\
\hline protein 8919 & $4.00 \times 10^{-8}$ & 54.12 & uncharacterized protein \\
\hline protein 2287 & $5.55 \times 10^{-16}$ & 44.36 & cathepsin B-like protein \\
\hline protein 8084 & $5.68 \times 10^{-14}$ & 7.2 & malate dehydrogenase \\
\hline protein 15939 & $4.35 \times 10^{-13}$ & 6.48 & Ras GTP-binding protein RhoL \\
\hline protein 4754 & $1.81 \times 10^{-9}$ & 5.96 & Hemerythrin-like protein \\
\hline protein 15039 & $1.81 \times 10^{-9}$ & 5.96 & Hemerythrin-like protein \\
\hline protein 17074 & $2.62 \times 10^{-6}$ & 4.88 & Unknown function (ORFan) \\
\hline protein 15365 & $1.43 \times 10^{-12}$ & 4.8 & predicted protein \\
\hline protein 13743 & $3.72 \times 10^{-6}$ & 4.7 & ubiquinone biosynthesis protein \\
\hline protein 8031 & $3.75 \times 10^{-8}$ & 4.11 & cathepsin B-like protein \\
\hline protein 4072 & $1.84 \times 10^{-8}$ & 4.02 & glyceraldehyde-3-phosphate dehydrogenase \\
\hline protein 17615 & $6.17 \times 10^{-6}$ & 3.95 & V-type $\mathrm{H}+$-transporting ATPase subunit $\mathrm{F}$ \\
\hline protein 2899 & $1.20 \times 10^{-9}$ & 3.24 & beta-tubulin \\
\hline protein 3274 & $7.59 \times 10^{-12}$ & 3.16 & adenylate kinase \\
\hline protein 7439 & $4.31 \times 10^{-8}$ & 2.99 & triosephosphate isomerase \\
\hline protein 7923 & $2.67 \times 10^{-4}$ & 2.82 & protein domain specific binding \\
\hline protein 12867 & $1.20 \times 10^{-5}$ & 2.78 & arsonoacetate metabolic process \\
\hline protein 2947 & $1.27 \times 10^{-11}$ & 2.65 & 3-oxoacid CoA-transferase activity \\
\hline protein 8114 & $1.69 \times 10^{-3}$ & 2.47 & cathepsin B-like protein \\
\hline protein 7780 & $4.69 \times 10^{-4}$ & 2.41 & pyruvate dehydrogenase \\
\hline protein 5985 & $2.67 \times 10^{-6}$ & 2.4 & alpha-actinin \\
\hline protein 3614 & $1.27 \times 10^{-10}$ & 2.39 & malate dehydrogenase \\
\hline protein 885 & $2.48 \times 10^{-7}$ & 2.39 & RRM domain-containing protein \\
\hline protein 13554 & $2.66 \times 10^{-10}$ & 2.39 & glutamate dehydrogenase \\
\hline protein 3571 & $5.22 \times 10^{-5}$ & 2.38 & Profilin \\
\hline protein 8014 & $5.79 \times 10^{-8}$ & 2.25 & phosphoenolpyruvate carboxykinase \\
\hline protein 6333 & $3.93 \times 10^{-3}$ & 2.21 & predicted protein \\
\hline protein 3628 & $1.13 \times 10^{-5}$ & 2.2 & cathepsin D \\
\hline protein 16124 & $1.07 \times 10^{-9}$ & 2.19 & ADP/ATP translocase 1 domain protein \\
\hline protein 8489 & $3.94 \times 10^{-6}$ & 2.19 & actin beta/gamma 1 \\
\hline protein 11280 & $1.15 \times 10^{-3}$ & 2.14 & $60 S$ ribosomal protein $\mathrm{L} 23$ \\
\hline protein 4486 & 6. $\times 10^{-11}$ & 2.13 & cystathionine gamma-lyase \\
\hline protein 2738 & $5.05 \times 10^{-5}$ & 2.12 & cathepsin B \\
\hline protein 8503 & $3.55 \times 10^{-10}$ & 2.11 & ATP synthase F1 subunit alpha \\
\hline protein 7955 & $3.57 \times 10^{-6}$ & 2.1 & large subunit ribosomal protein L24e \\
\hline protein 4073 & $7.58 \times 10^{-9}$ & 2.05 & fructose-bisphosphate aldolase \\
\hline protein 15452 & $3.15 \times 10^{-4}$ & 2.02 & malate metabolic process \\
\hline protein 2384 & $6.51 \times 10^{-9}$ & 2.02 & mitochondrial citrate synthetase \\
\hline protein 18191 & $2.88 \times 10^{-9}$ & 2.01 & thioredoxin \\
\hline
\end{tabular}


Table 2. Willaertia magna proteins up-regulated in suspension and down-regulated in adhesion culture.

\begin{tabular}{|c|c|c|c|}
\hline $\begin{array}{c}\text { Protein Sequence } \\
\text { Accession of } W . \text { magna }\end{array}$ & Anova (p) & Fold Change & Protein Function \\
\hline protein 5557 & $1.63 \times 10^{-10}$ & Infinity & Unknown protein (ORFan) \\
\hline protein 3984 & $4.59 \times 10^{-12}$ & 15.52 & large subunit ribosomal protein L7/L12 \\
\hline protein 2294 & $3.31 \times 10^{-13}$ & 11.34 & $\begin{array}{c}\text { metE; } \\
\text { 5-methyltetrahydropteroyltriglutamate- } \\
\text { homocysteine methyltransferase }\end{array}$ \\
\hline protein 16136 & $8.95 \times 10^{-14}$ & 5.98 & membrane protein \\
\hline protein 2157 & $5.28 \times 10^{-4}$ & 4.12 & ribosomal protein L7/L12, putative \\
\hline protein 10142 & $4.22 \times 10^{-14}$ & 3.43 & HSP-20 domain-containing protein \\
\hline protein 18401 & $8.68 \times 10^{-7}$ & 3.41 & nuclear transport factor 2 \\
\hline protein 18200 & $5.01 \times 10^{-6}$ & 2.84 & maleylacetoacetate isomerase \\
\hline protein 2831 & $8.88 \times 10^{-16}$ & 2.68 & HSP20 family protein \\
\hline protein 11490 & $2.19 \times 10^{-4}$ & 2.59 & predicted protein \\
\hline protein 2849 & $3.97 \times 10^{-8}$ & 2.49 & predicted protein \\
\hline protein 8080 & $3.66 \times 10^{-6}$ & 2.46 & long-chain acyl-CoA synthetase \\
\hline protein 11879 & $7.72 \times 10^{-5}$ & 2.3 & hypothetical protein \\
\hline protein 15002 & $2.04 \times 10^{-10}$ & 2.21 & membrane protein \\
\hline protein 16271 & $6.39 \times 10^{-12}$ & 2.18 & heat shock $70 \mathrm{kDa}$ protein 5 \\
\hline protein 3173 & $6.20 \times 10^{-6}$ & 2.18 & mitochondrial chaperonin hsp10 \\
\hline protein 14923 & $5.72 \times 10^{-7}$ & 2.15 & predicted protein \\
\hline protein 13231 & $5.57 \times 10^{-7}$ & 2.15 & sugar phosphate isomerase/epimerase \\
\hline protein 13228 & $3.71 \times 10^{-3}$ & 2.12 & predicted protein \\
\hline protein 6869 & $5.31 \times 10^{-7}$ & 2.07 & alcohol dehydrogenase \\
\hline protein 2046 & $7.87 \times 10^{-5}$ & 2.02 & catalase \\
\hline
\end{tabular}

\subsection{Analysis of Lipid Classes}

First, we described the lipid classes of the amoeba cultivated according to two different conditions. The LC/MS analysis reported overall similar lipid classes profiles, including apolar lipids, free fatty acids, phospholipids, sphingosines and lysophospholipids (Table S6). The peak areas for each lipid class were comparable between the culture conditions and these results were confirmed for both positive and negative electrospray ionization modes used in the study (Table S6). According to the LC/MS results, the lipid classes that exhibited the greatest signal were phospholipids, precisely phosphatidylcholines (PCs) and phosphatidylethanolamines (PEs) (Table S6). Nevertheless, the LC/MS analysis of lipid classes displayed different chromatogram peak profiles for cells cultivated under two different conditions (suspension and adhesion). Chromatogram profiles were comparable between samples and injection replicates. This fact suggests the presence of different chemical structures between the two conditions within the same lipid classes. The multivariate analysis of the raw data confirmed the structure differences by PCA for the positive and negative ionization modes independently (Table S7). We then attempted to identify the discriminating markers and their belonging class. The extracted ion chromatograms were compared to known standards and the exact masses computed with the LipidMAPS database (Table S7). The results are summarized in Table 3. These results showed fewer markers in the case of cells grown in suspension. The adhesion culture indicated several lysophospholipid markers and a greater diversity of glycolipid or phospholipid markers. In a second time, we investigated the composition of total fatty acids (free and included in complex lipids, such as phospholipids or acylglycerols). Comparative analysis of total fatty acids profiles revealed similar classes of structure, namely saturated, unsaturated and branched carbon chains (Table S8). 
Yet, wel found a higher abundance of longer carbon backbones for the amoebas cultivated in the adhesion mode (Table S8).

Table 3. Identification of lipid markers related to different culture modes.

\begin{tabular}{|c|c|c|}
\hline Culture Condition & Suspension & Adhesion \\
\hline Positive ionization & $\begin{array}{c}4 \text { apolar lipids (1 Ceramide, } 3 \\
\text { Acylglycerols) } \\
4 \text { Glyco lipids } \\
\text { (Glycosyldiacylglycerols) } \\
11 \text { phospholipids (6 PCs, } 5 \\
\text { unknown) }\end{array}$ & $\begin{array}{c}2 \text { apolar lipids (Acylglycerols) } \\
5 \text { Glyco lipids (3 Hex Sphingosine, } 2 \\
\text { Glycosyldiacylglycerols) } \\
7 \text { Phospholipids (3 PCs, } 1 \text { phosphatidyl serine, } \\
3 \text { unknown) } \\
\text { 7 Lysophospholipids }\end{array}$ \\
\hline Negative ionization & $\begin{array}{c}2 \text { apolar lipids (Ceramides) } \\
8 \text { Free Fatty Acids (7 identified) } \\
6 \text { phospholipids ( } 1 \text { PE, } 5 \text { PC) } \\
1 \text { lysophospholipid }\end{array}$ & $\begin{array}{c}5 \text { apolar lipid (1 Ceramide, } 1 \text { Wax Ester, } 1 \\
\text { Coenzyme A, } 2 \text { unknown) } \\
2 \text { Glyco lipids (1 Ceramide, } 1 \\
\text { Glycosyldiacylglycerol) } \\
\text { 13 Free Fatty Acids (6 identified) } \\
6 \text { Phospholipids (1 phosphatidylinositol, } 1 \\
\text { phosphatidic acid, } 4 \text { PEs) } \\
\text { 14 Lysophospholipids }\end{array}$ \\
\hline
\end{tabular}

\section{Discussion}

For the first time, the behavior of a FLA is compared according to two culture modes using multi-omics approaches.

A previous transcriptomics and proteomics study showed that W. magna C2c Maky cultivated in a bioreactor had the weapons to deal with bacterial attacks in the environment [33]. Indeed, we detected production of several proteins involved in the mechanism defenses of eukaryotic organisms against foreign microbes. Among the proteins detected in the DRP study, we observed that the essential proteins associated with the defense mechanisms were not differentially regulated and were therefore probably not impacted by the culture method.

However, we reported some differences between the two culture modes for the cell growth. Indeed, the protist seems to promote the metabolism of carbohydrate when cultivated in adhesion. This finding was correlated with an over-regulation of proteins related to energy. Culture media were similar for each cell growth, but fetal bovine serum (FBS) was removed from the amoebal culture in suspension to reduce the cost of large-scale cultivation. We can suggest that the proteins and growth factors contained in the FBS could improve the assimilation of glucose by W. magna in adhesion culture. Therefore, a source of carbohydrate (other than glucose) could be added to the media to provide more energy at the cells cultivated in suspension. Glucose oxidation is an important energy source for cells; however, this process generates the formation of reactive oxygen species (ROS) extremely harmful to the cells. To mediate the oxidative stress, thioredoxin proteins were over-regulated for W. magna cultivated in adhesion [62,63]. The energy provided by carbohydrate metabolism is notably essential to ensure amoeboid mobility and maintaining the cytoskeleton. Among the DRPs, we observed the over-regulation of proteins related to the cytoskeleton structure. Amoebas migration is initiated by the polymerization of actin that allows the formation of the organelle indispensable for amoeboid movement [64]. The over-regulation of these proteins revealed a dynamic activity of W. magna cultured in adhesion. In addition, these results were correlated with the large size and quantity of amoeba pseudopods in adhesion culture.

When W. magna was cultured in bioreactor, we observed over-regulation of long-chain acyl-coenzyme A (CoA) synthetase and alcohol dehydrogenase which are proteins involved in the lipid metabolism pathway. Alcohol dehydrogenase is an enzyme regulating the biosynthetic pathway of glycerol [65]. This carbon source is converted into intermediate metabolites used for the lipid biosynthesis, including the formation of fatty acids activated through acyl-CoA [66,67]. In addition, we found an over-regulation of homocysteine methyltransferase protein, which is an 
enzyme implicated in methionine formation [68]. This enzyme is also known to be involved in the metabolism of PCs, a class of over-represented lipids for the amoebas cultivated in bioreactor (in suspension). The use of choline or homocysteine, which are precursors of methionine, could be beneficial to improve the culture of amoebas in bioreactors. Otherwise, the stress of cells cultivated in suspension was revealed by the over-regulation of heat-shock proteins. A drop-in culture temperature could thus allow the production of less stressed cells.

An investigation on total lipid classes was achieved to complement the proteomics analysis. Our survey has shown that amoebas are composed of a similar set of lipid classes regardless of the culture mode. Interestingly, we found that phospholipids were the most represented lipids for W. magna cultivated in the two culture modes. However, we pointed out specific lipid markers according to the culture condition used. Thus, growth cell in adhesion showed the presence of specific glycolipid markers that could be related to the physical state of the amoebas and that could be involved in cell-to-cell interactions $[69,70]$. Noteworthy, glycosphingolipids are known to be involved in the cell-to-cell communication [71,72]. In adhesion, W. magna consumed a large amount of carbohydrates, which could be correlated with a high proportion of glycosylated lipids. Lysophospholipids have been reported to be involved in the membrane shaping process and bending, but also as mediators in signaling cascades for migration or cell-to-cell attachment $[73,74]$. Their increase during adhesion cell growth compared to suspension could therefore be linked to these processes. W. magna cells in adhesion compared to the suspension condition exhibited the formation of phosphatidic acid structures, which are usual minor components of the cell membrane. Speranza et al. reported the interaction of PAs with actin-related proteins in order to promote actin polymerization [75]. The higher contents of phosphatidylcholine lipid markers that we observed in suspension culture condition could be related to these proteomics results.

\section{Conclusions}

In conclusion, the study allowed to improve knowledge on the understudied amoebic field. This survey provides new insights into the mechanisms used by W. magna to adapt to different culture conditions. Indeed, W. magna regulated its protein and lipid metabolism to grow in different culture conditions. Therefore, multi-omics approaches are essential tools to study the molecular responses and biology of FLAs.

Supplementary Materials: The following are available online at http://www.mdpi.com/2076-2607/8/11/1791/s1. Supplementary data (word file) contain Figure S1 and Table S3, Figure S1: comparison between qRT-PCR and proteomic results of abundance proteins, Table S1: data obtained from protein extractions of W. magna cultivated in different culture conditions, Table S2: The results obtained from proteomics analysis, Table S3: primers used for the quantification of mRNAs expression level by qRT-PCR, Table S4: measuring the length and width of the amoebas cultivated under two different conditions, Table S5: identification and annotation of the DRPs, Table S6: data of lipid classes profiles performed by LC/MS analysis, Table S7: identification of lipid markers related to different culture modes, Table S8: analysis of total fatty acids profiles.

Author Contributions: I.H. performed microscopic, proteomic and lipidomic analyzes and wrote the manuscript, N.A. performed lipidomic analyze and wrote the manuscript, P.D. performed proteomic experiment, S.A. performed protein extraction, A.F. performed microscopic pictures, O.A. performed and supervised the culture of the amoebas in bioreactor, A.C.L. analyzed the results, S.D. supervised the study and reviewed the manuscript, E.C. supervised the study, P.C. supervised the study and reviewed the manuscript, B.L.S. conceived and supervised the study and wrote the manuscript. All authors have read and agreed to the published version of the manuscript.

Funding: This work was supported by a grant from the French State managed by the National Research Agency under the "Investissements d'avenir (Investments for the Future)" program under the reference ANR-10-IAHU-03 (Méditerranée Infection) and by the Région Provence-Alpes-Côte-d'Azur and the European funding FEDER PRIMMI.

Conflicts of Interest: I. Hasni had a CIFRE grant supported by Amoeba society, O. Abbe and S. Demanèche are employed by Amoeba company. 


\section{References}

1. Pánek, T.; Čepička, I. Diversity of Heterolobosea. In Generic Diversity in Microorgisms; Caliskan, M., Ed.; IntechOpen: London, UK, 2012; ISBN 978-953-51-0064-5. [CrossRef]

2. Adl, S.M.; Bass, D.; Lane, C.E.; Lukeš, J.; Schoch, C.L.; Smirnov, A.; Agatha, S.; Berney, C.; Brown, M.W.; Burki, F.; et al. Revisions to the Classification, Nomenclature, and Diversity of Eukaryotes. J. Eukaryot. Microbiol. 2019, 66, 4-119. [CrossRef] [PubMed]

3. Conza, L.; Pagani, S.C.; Gaia, V. Presence of Legionella and Free-Living Amoebae in Composts and Bioaerosols from Composting Facilities. PLoS ONE 2013, 8, e68244. [CrossRef] [PubMed]

4. De Jonckheere, J.F.; Dive, D.G.; Pussard, M.; Vickerman, K. Willaertia magna gen. nov., sp. nov. (Vahlkampfiidae), a thermophilic amoeba found in different habitats. Protistologica 1984, 201, 5-13.

5. Dobson, P.J.; Robinson, B.S.; Christy, P.; Hayes, S.J. Low Genetic Diversity in Willaertia Magna From Wide Geographical Sources, and Characterisation of Willaertia Minor N. Sp. (Heterolobosea, Vahlkampfidae). J. Eukaryot. Microbiol. 1993, 40, 298-304. [CrossRef]

6. Robinson, B.; Christy, P.; De Jonckheere, J. A temporary flagellate (mastigote) stage in the vahlkampfiid amoeba Willaertia magna and its possible evolutionary significance. Biosystems 1989, 23, 75-86. [CrossRef]

7. Rivera, F.; Lares, F.; Gallegos, E.; Ramírez, E.; Bonilla, P.; Calderon, A.; Martinez, J.J.; Rodríguez, S.; Alcocer, J. Pathogenic amoebae in natural thermal waters of three resorts of Hidalgo, Mexico. Environ. Res. 1989, 50, 289-295. [CrossRef]

8. Hasni, I.; Chelkha, N.; Baptiste, E.; Mameri, M.R.; Lachuer, J.; Plasson, F.; Colson, P.; La Scola, B. Investigation of potential pathogenicity of Willaertia magna by investigating the transfer of bacteria pathogenicity genes into its genome. Sci. Rep. 2019, 9, 18318. [CrossRef]

9. Stout, J.E.; Yu, V.L. Legionellosis. N. Engl. J. Med. 1997, 337, 682-687. [CrossRef]

10. Borella, P.; Guerrieri, E.; Marchesi, I.; Bondi, M.; Messi, P. Water ecology of Legionella and protozoan: Environmental and public health perspectives. Biotechnol. Annu. Rev. 2005, 11, 355-380. [CrossRef]

11. Hamilton, K.A.; Prussin, A.J.; Ahmed, W.; Haas, C.N. Outbreaks of Legionnaires' Disease and Pontiac Fever 2006-2017. Curr. Environ. Heal. Rep. 2018, 5, 263-271. [CrossRef]

12. Yamamoto, H.; Sugiura, M.; Kusunoki, S.; Ezaki, T.; Ikedo, M.; Yabuuchi, E. Factors stimulating propagation of legionellae in cooling tower water. Appl. Environ. Microbiol. 1992, 58, 1394-1397. [CrossRef] [PubMed]

13. Rowbotham, T.J. Preliminary report on the pathogenicity of Legionella pneumophila for freshwater and soil amoebae. J. Clin. Pathol. 1980, 33, 1179-1183. [CrossRef] [PubMed]

14. Kilvington, S.; Price, J. Survival of Legionella pneumophila within cysts of Acanthamoeba polyphagafollowing chlorine exposure. J. Appl. Bacteriol. 1990, 68, 519-525. [CrossRef] [PubMed]

15. Winiecka-Krusnell, E.L.J. Free-living Amoebae Protecting Legionella in Water: The Tip of an Iceberg? Scand. J. Infect. Dis. 1999, 31, 383-385. [CrossRef] [PubMed]

16. Cirillo, J.D.; Falkow, S.; Tompkins, L.S. Growth of Legionella pneumophila in Acanthamoeba castellanii enhances invasion. Infect. Immun. 1994, 62, 3254-3261. [CrossRef] [PubMed]

17. Greub, G.; Raoult, D. Microorganisms Resistant to Free-Living Amoebae. Clin. Microbiol. Rev. 2004, 17, 413-433. [CrossRef] [PubMed]

18. Rowbotham, T.J. Isolation of Legionella pneumophila from clinical specimens via amoebae, and the interaction of those and other isolates with amoebae. J. Clin. Pathol. 1983, 36, 978-986. [CrossRef]

19. Dey, R.; Bodennec, J.; Mameri, M.O.; Pernin, P. Free-living freshwater amoebae differ in their susceptibility to the pathogenic bacterium Legionella pneumophila. FEMS Microbiol. Lett. 2009, 290, 10-17. [CrossRef]

20. Hasni, I.; Jarry, A.; Quelard, B.; Carlino, A.; Eberst, J.-B.; Abbe, O.; Demanèche, S. Intracellular Behaviour of Three Legionella pneumophila Strains within Three Amoeba Strains, Including Willaertia magna C2c Maky. Pathogens 2020, 9, 105. [CrossRef]

21. Abu Khweek, A.; Amer, A.O. Factors Mediating Environmental Biofilm Formation by Legionella pneumophila. Front. Cell. Infect. Microbiol. 2018, 8, 38. [CrossRef]

22. Beshay, U.; Friehs, K.; Azzam, A.-E.-M.; Flaschel, E. Analysis of the behaviour of Dictyostelium discoideum in immobilised state by means of continuous cultivation. Bioprocess Biosyst. Eng. 2003, 26, 117-122. [CrossRef] [PubMed] 
23. Weekers, P.H.H.; Wijen, J.P.H.; Lomans, B.P.; Vogels, G.D. Axenic mass cultivation of the free-living soil amoeba, Acanthamoeba castellanii in a laboratory fermentor. Antonie Leeuwenhoek 1996, 69, 317-322. [CrossRef] [PubMed]

24. Weekers, P.H.; Vogels, G.D. Axenic cultivation of the free-living amoebae, Acanthamoeba castellanii and Hartmannella vermiformis in a chemostat. J. Microbiol. Methods 1994, 19, 13-18. [CrossRef]

25. Tian, J.; Ishibashi, K.; Honda, S.; Boylan, S.A.; Hjelmeland, L.M.; Handa, J.T. The expression of native and cultured human retinal pigment epithelial cells grown in different culture conditions. Br. J. Ophthalmol. 2005, 89, 1510-1517. [CrossRef] [PubMed]

26. Plain, N.; Largeau, C.; Derenne, S.; Couté, A. Variabilité morphologique de Botryococcus braunii (Chlorococcales, Chlorophyta): Corrélations avec les conditions de croissance et la teneur en lipides. Phycologia 1993, 32, 259-265. [CrossRef]

27. Ponec, M.; Weerheim, A.; Kempenaar, J.; Elias, P.M.; Williams, M.L. Differentiation of cultured human keratinocytes: Effect of culture conditions on lipid composition of normal vs. malignant cells. Vitr. Cell. Dev. Biol. Anim. 1989, 25, 689-696. [CrossRef]

28. Gallagher, J.E.; Zheng, W.; Rong, X.; Miranda, N.; Lin, Z.; Dunn, B.; Zhao, H.; Snyder, M.P. Divergence in a master variator generates distinct phenotypes and transcriptional responses. Genes Dev. 2014, 28, 409-421. [CrossRef]

29. Britto, J.A.; Evans, R.D.; Hayward, R.D.; Jones, B.M. From Genotype to Phenotype: The Differential Expression of FGF, FGFR, and TGF $\beta$ Genes Characterizes Human Cranioskeletal Development and Reflects Clinical Presentation in FGFR Syndromes. Plast. Reconstr. Surg. 2001, 108, 2026-2039. [CrossRef]

30. Yang, K.; Han, X. Lipidomics: Techniques, Applications, and Outcomes Related to Biomedical Sciences. Trends Biochem. Sci. 2016, 41, 954-969. [CrossRef]

31. O’Donnell, S.T.; Ross, R.P.; Stanton, C. The Progress of Multi-Omics Technologies: Determining Function in Lactic Acid Bacteria Using a Systems Level Approach. Front. Microbiol. 2020, 10, 3084. [CrossRef]

32. Subramanian, I.; Verma, S.; Kumar, S.; Jere, A.; Anamika, K. Multi-omics Data Integration, Interpretation, and Its Application. Bioinform. Biol. Insights 2020, 14, 14. [CrossRef] [PubMed]

33. Hasni, I.; Decloquement, P.; Demanèche, S.; Mameri, R.M.; Abbe, O.; Colson, P.; La Scola, B. Insight into the Lifestyle of Amoeba Willaertia magna during Bioreactor Growth Using Transcriptomics and Proteomics. Microorganisms 2020, 8, 771. [CrossRef] [PubMed]

34. Clarke, M.; Lohan, A.J.; Liu, B.; Lagkouvardos, I.; Roy, S.; Zafar, N.; Bertelli, C.; Schilde, C.; Kianianmomeni, A.; Buerglin, T.R.; et al. Genome of Acanthamoeba castellanii highlights extensive lateral gene transfer and early evolution of tyrosine kinase signaling. Genome Biol. 2013, 14, R11. [CrossRef] [PubMed]

35. Fritz-Laylin, L.K.; Prochnik, S.E.; Ginger, M.L.; Dacks, J.B.; Carpenter, M.L.; Field, M.C.; Kuo, A.; Paredez, A.; Chapman, J.; Pham, J.; et al. The Genome of Naegleria gruberi Illuminates Early Eukaryotic Versatility. Cell 2010, 140, 631-642. [CrossRef] [PubMed]

36. Liechti, N.; Schürch, N.; Bruggmann, R.; Wittwer, M. The genome of Naegleria lovaniensis, the basis for a comparative approach to unravel pathogenicity factors of the human pathogenic amoeba N. fowleri. BMC Genom. 2018, 19, 1-11. [CrossRef]

37. Zysset-Burri, D.C.; Müller, N.; Beuret, C.M.; Heller, M.; Schürch, N.; Gottstein, B.; Wittwer, M. Genome-wide identification of pathogenicity factors of the free-living amoeba Naegleria fowleri. BMC Genom. 2014, 15, 496.[CrossRef]

38. Liechti, N.; Schürch, N.; Bruggmann, R.; Wittwer, M. Nanopore sequencing improves the draft genome of the human pathogenic amoeba Naegleria fowleri. Sci. Rep. 2019, 9, 16040. [CrossRef]

39. Chelkha, N.; Hasni, I.; Louazani, A.C.; Levasseur, A.; La Scola, B.; Colson, P. Vermamoeba vermiformis CDC-19 draft genome sequence reveals considerable gene trafficking including with candidate phyla radiation and giant viruses. Sci. Rep. 2020, 10, 5928. [CrossRef]

40. Hasni, I.; Andreani, J.; Colson, P.; La Scola, B. Description of Virulent Factors and Horizontal Gene Transfers of Keratitis-Associated Amoeba Acanthamoeba Triangularis by Genome Analysis. Pathogens 2020, 9, 217. [CrossRef]

41. Detering, H.; Aebischer, T.; Dabrowski, P.W.; Radonic, A.; Nitsche, A.; Renard, B.Y.; Kiderlen, A.F. First Draft Genome Sequence ofBalamuthia mandrillaris, the Causative Agent of Amoebic Encephalitis. Genome Announc. 2015, 3, e01013-15. [CrossRef] 
42. Greninger, A.L.; Messacar, K.; Dunnebacke, T.; Naccache, S.N.; Federman, S.; Bouquet, J.; Mirsky, D.M.; Nomura, Y.; Yagi, S.; Glaser, C.A.; et al. Clinical metagenomic identification of Balamuthia mandrillaris encephalitis and assembly of the draft genome: The continuing case for reference genome sequencing. Genome Med. 2015, 7, 1-14. [CrossRef] [PubMed]

43. De Jonckheere, J. Use of an axenic medium for differentiation between pathogenic and nonpathogenic Naegleria fowleri isolates. Appl. Environ. Microbiol. 1977, 33, 751-757. [CrossRef] [PubMed]

44. Bioréacteur Pilote GPC. Available online: http://www.gpcbio.com/bioracteurpilote.html (accessed on 21 March 2020).

45. Renesto, P.; Abergel, C.; Decloquement, P.; Moinier, D.; Azza, S.; Ogata, H.; Fourquet, P.; Gorvel, J.-P.; Claverie, J.-M. Mimivirus Giant Particles Incorporate a Large Fraction of Anonymous and Unique Gene Products. J. Virol. 2006, 80, 11678-11685. [CrossRef] [PubMed]

46. Altschul, S.F.; Gish, W.; Miller, W.; Myers, E.W.; Lipman, D.J. Basic local alignment search tool. J. Mol. Biol. 1990, 215, 403-410. [CrossRef]

47. Tatusov, R.L.; Galperin, M.Y.; Natale, D.A.; Koonin, E.V. The COG database: A tool for genome-scale analysis of protein functions and evolution. Nucleic Acids Res. 2000, 28, 33-36. [CrossRef] [PubMed]

48. Huerta-Cepas, J.; Forslund, K.; Coelho, L.P.; Szklarczyk, D.; Jensen, L.J.; Von Mering, C.; Bork, P. Fast Genome-Wide Functional Annotation through Orthology Assignment by eggNOG-Mapper. Mol. Biol. Evol. 2017, 34, 2115-2122. [CrossRef]

49. Ye, J.; Zhang, Y.; Cui, H.; Liu, J.; Wu, Y.; Cheng, Y.; Xu, H.; Huang, X.; Li, S.; Zhou, A.; et al. WEGO 2.0: A web tool for analyzing and plotting GO annotations, 2018 update. Nucleic Acids Res. 2018, 46, W71-W75. [CrossRef]

50. Kanehisa, M.; Sato, Y.; Morishima, K. BlastKOALA and GhostKOALA: KEGG Tools for Functional Characterization of Genome and Metagenome Sequences. J. Mol. Biol. 2016, 428, 726-731. [CrossRef]

51. Hunter, S.; Apweiler, R.; Attwood, T.K.; Bairoch, A.; Bateman, A.; Binns, D.; Bork, P.; Das, U.; Daugherty, L.; Duquenne, L.; et al. InterPro: The integrative protein signature database. Nucleic Acids Res. 2009, 37, D211-D215. [CrossRef]

52. Quevillon, E.; Silventoinen, V.; Pillai, S.; Harte, N.; Mulder, N.J.; Apweiler, R.; Lopez, R. InterProScan: Protein domains identifier. Nucleic Acids Res. 2005, 33, W116-W120. [CrossRef]

53. Marchler-Bauer, A.; Derbyshire, M.K.; Gonzales, N.R.; Lu, S.; Chitsaz, F.; Geer, L.Y.; Geer, R.C.; He, J.; Gwadz, M.; Hurwitz, D.I.; et al. CDD: NCBI's conserved domain database. Nucleic Acids Res. 2015, 43, D222-D226. [CrossRef] [PubMed]

54. Livak, K.J.; Schmittgen, T.D. Analysis of relative gene expression data using real-time quantitative PCR and the $2^{-\Delta \Delta C T}$ Method. Methods 2001, 25, 402-408. [CrossRef] [PubMed]

55. Li, J.; Ding, X.; Han, S.; He, T.; Zhang, H.; Yang, L.; Yang, S.; Gai, J. Differential proteomics analysis to identify proteins and pathways associated with male sterility of soybean using iTRAQ-based strategy. J. Proteom. 2016, 138, 72-82. [CrossRef] [PubMed]

56. Bligh, E.G.; Dyer, W.J. A Rapid Method of Total Lipid Extraction and Purification. Can. J. Biochem. Physiol. 1959, 37, 911-917. [CrossRef]

57. Isaac, G.; McDonald, S.; Astarita, G. Lipid Separation Using UPLC with Charged Surface Hybrid Technology, Milfort: Waters Application Note. 2011. Available online: https:/www.waters.com/webassets/cms/library/ docs/720004107en.pdf (accessed on 9 September 2020).

58. Čabovska, B. Application of Multivariate Analysis and LC-MS for the Detection of Counterfeit Cosmetics. Waters Application Note. 2015. Available online: https://www.waters.com/webassets/cms/library/docs/ 720005402en.pdf (accessed on 9 September 2020).

59. Dione, N.; Sankar, S.; Lagier, J.-C.; Khelaifia, S.; Michele, C.; Armstrong, N.; Richez, M.; Abrahão, J.; Raoult, D.; Fournier, P.-E. Genome sequence and description of Anaerosalibacter massiliensis sp. nov. New Microbes New Infect. 2016, 10, 66-76. [CrossRef] [PubMed]

60. Ngom, I.; Hasni, I.; Lo, C.; Traore, S.; Fontanini, A.; Raoult, D.; Fenollar, F. Taxono-genomics and description of Gordonibacter massiliensis sp. nov., a new bacterium isolated from stool of healthy patient. New Microbes New Infect. 2020, 33, 100624. [CrossRef]

61. Sasser, M. Bacterial Identification by Gas Chromatographic Analysis of Fatty Acid Methyl Esters (GC-FAME); Technical Note 101; MIDI Inc.: Newark, DE, USA, 2006; Available online: http://midi-inc.com/pdf/MIS_ Technote_101.pdf (accessed on 9 September 2020). 
62. Ahsan, K.; Lekli, I.; Ray, D.; Yodoi, J.; Das, D.K. Redox Regulation of Cell Survival by the Thioredoxin Superfamily: An Implication of Redox Gene Therapy in the Heart. Antioxid. Redox Signal. 2009, 11, 2741-2758. [CrossRef]

63. Netto, L.E.S.; Antunes, A.F. The Roles of Peroxiredoxin and Thioredoxin in Hydrogen Peroxide Sensing and in Signal Transduction. Mol. Cells 2016, 39, 65-71. [CrossRef]

64. Zigmond, S.H. How Wasp Regulates Actin Polymerization. J. Cell Biol. 2000, 150, F117-F120. [CrossRef]

65. Hagopian, K.; Ramsey, J.J.; Weindruch, R. Enzymes of glycerol and glyceraldehyde metabolism in mouse liver: Effects of caloric restriction and age on activities. Biosci. Rep. 2008, 28, 107-115. [CrossRef]

66. Wendel, A.A.; Lewin, T.M.; Coleman, R.A. Glycerol-3-phosphate acyltransferases: Rate limiting enzymes of triacylglycerol biosynthesis. Biochim. et Biophys. Acta (BBA) Mol. Cell Biol. Lipids 2009, 1791, 501-506. [CrossRef] [PubMed]

67. Xue, L.-L.; Chen, H.-H.; Jiang, J.-G. Implications of glycerol metabolism for lipid production. Prog. Lipid Res. 2017, 68, 12-25. [CrossRef] [PubMed]

68. Zeisel, S.H. Choline, Other Methyl-Donors and Epigenetics. Nutrients 2017, 9, 445. [CrossRef] [PubMed]

69. Ohtsubo, K.; Marth, J.D. Glycosylation in Cellular Mechanisms of Health and Disease. Cell 2006, 126, 855-867. [CrossRef] [PubMed]

70. Kopitz, J. Lipid glycosylation: A primer for histochemists and cell biologists. Histochem. Cell Biol. 2016, 147, 175-198. [CrossRef]

71. Van Meer, G.; Wolthoorn, J.; DeGroote, S. The fate and function of glycosphingolipid glucosylceramide. Philos. Trans. R. Soc. B Biol. Sci. 2003, 358, 869-873. [CrossRef]

72. DeGroote, S.; Wolthoorn, J.; Van Meer, G. The cell biology of glycosphingolipids. Semin. Cell Dev. Biol. 2004, 15, 375-387. [CrossRef]

73. Rivera, R.; Chun, J. Biological effects of lysophospholipids. Rev. Physiol. Biochem. Pharmacol. Biochem. Pharmacol. 2006, 160, 25-46.

74. Ailte, I.; Lingelem, A.B.D.; Kavaliauskiene, S.; Bergan, J.; Kvalvaag, A.S.; Myrann, A.-G.; Skotland, T.; Sandvig, K. Addition of lysophospholipids with large head groups to cells inhibits Shiga toxin binding. Sci. Rep. 2016, 6, 30336. [CrossRef]

75. Speranza, F.; Mahankali, M.; Henkels, K.M.; Gómez-Cambronero, J. The Molecular Basis of Leukocyte Adhesion Involving Phosphatidic Acid and Phospholipase D. J. Biol. Chem. 2014, 289, 28885-28897. [CrossRef]

Publisher's Note: MDPI stays neutral with regard to jurisdictional claims in published maps and institutional affiliations.

(C) 2020 by the authors. Licensee MDPI, Basel, Switzerland. This article is an open access article distributed under the terms and conditions of the Creative Commons Attribution (CC BY) license (http://creativecommons.org/licenses/by/4.0/). 